\title{
REVIEW OF ERIK RINGMAR, HISTORY OF INTERNATIONAL RELATIONS: A NON-EUROPEAN PERSPECTIVE, OPEN BOOK PUBLISHERS, CAMBRIDGE 2019, PP. 206, ISBN 978-1-78374-022-2
}

\author{
Marcin Nabożny*
}

\section{INTRODUCTION}

International politics, as usually taught, is hopelessly Eurocentric. History takes Europe as the standard by which every other part of the world is measured, although "Europe" here also includes the United States and other places where Europeans settled. The book is not interested in telling a story as long as history itself nor is it interested in the events, wars, names, and dates of the past, but the aim is to introduce you to a subject that we could call the "comparative study of international systems." Today, there is only one international system. This is the system that originated in Europe and spread to the rest of the world, as a result of European colonialism in the nineteenth century. As a result, the different international systems that previously existed were destroyed and the entire world has been recreated in Europe's image.

The project is funded by the Minister of Science and Higher Education within the program under the name "Regional Initiative of Excellence" in 2019-2022, project number: 028/RID/2018/19, the amount of funding: 11742500 PLN.

Dr. Marcin Nabożny, Research Associate, Faculty of Theology, The John Paul II Catholic University of Lublin; correspondence address: Al. Racławickie 14, 20-950 Lublin, Poland; e-mail: marcin.nabozny@gmail.com; https://orcid.org/0000-0003-4628-8495. 


\section{ABOUT THE BOOK}

The book History of International Relations: A non-European Perspective was written by Erik Ringmar and published by Open Book Publishers, Cambridge, UK in 2019. It is a historical book that goes back to the first millennium of the Common Era with an explicit non-European perspective. It is a book on international politics which puts Europe firmly in its place while taking a historical look at the world as a whole. Furthermore, just to be clear, this alternative perspective is not motivated by an attempt to be "politically correct." The aim is not to set the record straight out of a concern for balance or respect for people who are marginalized and silenced. But more straightforwardly to provide a better account of the kind of knowledge we need in order to understand today's world. The book dares to change the narrative of the history of international relations that is taught today. It has 206 pages, with 9 maps and 102 online sources across 8 chapters.

\section{ABOUT THE AUTHOR}

Erik Ringmar was born on December 10, 1960 in Sweden. He is a professor in the Department of Political Science and International Relations at Ibn University, Istanbul, Turkey. He graduated from Yale University in 1993 with a $\mathrm{PhD}$ in political science and has subsequently worked at the London school of Economics and as professor of international politics at Shanghai Jiaotong Daxue in Shanghai, China. In the summer of 2008 he underwent successful cancer surgery, an experience that he chronicled online.

\section{CONTEXT/ REVIEW}

China itself was an empire, at the same time, there was a great difference in the way the Chinese dealt with neighbors to the north and the west of the country and neighbors to the south and the east. The people to the north and west constituted permanent threats. Since the terrain 
was flat and since there were few natural obstacles in the way, it was easy for the nomads to raid Chinese farming communities. Occasionally they made it all the way to the capital itself. The imperial authorities always struggled with how best to respond to these threats, mixing defensive and offensive strategies without ever finding a satisfactory solution. As a result, China was periodically invaded and two major dynasties were founded by tribes from the steppes: the Yuan, 1271-1368, which was of Mongol origin, and the last imperial dynasty, the Qing, 1644-1911, which was Manchu.

It was always difficult for the Chinese to defend themselves against these threats. The steppes were easily crossed by the nomads on their swift horses, but they were far more difficult for Chinese armies to cross on foot. Deserts like the Gobi and the Taklamakan constituted obstacles for both parties, but they were far more likely to keep the Chinese in than the nomads out. Moreover, the people of the steppes were ferocious warriors. Although they, initially at least, had little means of military technology and few inventions of their own, they had access to the best horses in the world. On the back of a horse, they could cover large distances very quickly and attack an enemy at full speed, wielding their spears and firing off arrows with high precision. The perennial question for the Chinese was how best to deal with enemies such as these. The most obvious option was to pursue a defensive strategy, and this is what the Chinese did for much of their history. One way to do this was to build walls.

Impressive as these physical structures no doubt were, a defensive strategy never worked all that well. The Mongols soon learned how to besiege a city using catapults and various ingenious siege engines. For that reason, it was better for the Chinese to go on the offense, and this is what the emperors did on numerous occasions. The first Han emperor undertook large military campaigns which were continued by his successors.

During the subsequent two thousand years, the leaders of the Chinese state would all be referred to as "emperors" and the country itself referred to as an "empire." Yet since one dynasty was constantly replaced by another, there is little continuity in Chinese history and struggles for political power resulted in both revolutions and prolonged periods of wars. The most important dynasties were the: Han, Tang, Song, Ming and Qing. 
Towards the end of the Zhou dynasty, political power began to fragment as regional leaders who had been given land by the kings asserted their independence. Eventually, seven separate states emerged, and they were constantly at war with each other. This period has been reported to as the "Warring States period."

The art of war is a manual of military strategy and tactics ascribed to Sunzi, 544-496 BCE, a general active during the Warring States period. Although there indeed was a general by that name, it is not entirely clear that he was the author of the work in question, although in China the book is known as Sunzi bingfa, or "Master Sun's Rules for Soldiers." Sunzi emphasized the importance of intelligence gathering, of subterfuge and dissimulation, but he also discussed the role of diplomacy, and how best to deploy troops.

Konzi, 551-479 BCE better known outside of China a Confucius is the most famous of these wandering scholars. Born in the state of $\mathrm{Lu}$ in what today is the Shadong province the peninsula which juts out in the direction of Korea, Konzi rose from lowly jobs as a cow-herder and clerk to become an adviser to the king of Lu himself. Yet, eventually, political intrigues forced him to leave the court; this was when his life as a peripatic teacher began. Konzi's philosophy emphasized the importance of personal conduct and he insisted that the virtue of the rulers was more important than the formal rules by which the state was governed.

Since there was no way for foreigners to enter China except as tribute bearers, tribute bearers were what all foreigners who arrived in China became. This included foreign merchants. Barbarians, however, were not to be feared as much as pitied, and the fact that they had showed up on China's doorstep proved that they were willing to learn from the Chinese. As such they were to be treated benevolently. By coming to China, and by submitting themselves to the rules prescribed by the tribute system, the foreigners assumed their designated place in the Chinese order of things. A detailed protocol regulated these visits. Each mission was not to exceed one hundred men, of whom only twenty were allowed to proceed to the capital while the rest remained at the border. On their way to Beijing, each delegation was fed, housed and transported at the emperor's expense; and once they arrived they stayed in the official "Residence for Tributary Envoys," where they are given a statutory amount of silver, rice, 
and other foodstuffs. Both coming and going, they were accompanied by imperial troops who both protected them and controlled their movements. The highlight of the mission was the audience with the emperor.

Once the first contacts were established with China in the fifth century $\mathrm{CE}$, the inhabitants of the islands of Japan maintained a close relationship to the Asian mainland. When they eventually made it back to Japan, they had amazing stories to tell about all the wonders they had seen. The Japanese imported an entire culture from China. Once the Mongols tried, and failed to invade China at the end of the thirteenth century, relations could not continue as before.

A further similarity with China is that India too has constantly been menaced by invasions. Surplus agricultural goods financed an elaborate hierarchy of social classes and powerful states with rulers famous for their ostentatious display of wealth. The Mughals were Muslims and their culture was to have a profound impact on Indian society. Yet Hindu traditions remained strong. Even the most powerful of foreign conquerors had to make compromises with Indian ways of life. India has exercised a powerful influence over the rest of Asia, and over Southeast Asia in particular. Starting in the first centuries of the Common Era, Indian cultural practices, and ideas regarding society and religion were disseminated all around the Indian Ocean, leading to new cultural combinations.

The first written records of Indian history are the Vedas, a large body of religious texts dating from around $1500 \mathrm{BCE}$. The Vedas are based on secret oral teachings provided by religious teachers and they heavily emphasize rituals, including sacrifice of various kinds. The followers of the Vedas were the Indo-Europeans sometimes known as "Aryans." The Indo-Europeans were originally pastoralists and even though they increasingly turned to family, cattle breeding continued to be important in their lives. The cow was already at this time a sacred animal. Not that much is known about the Indo-Europeans, but the Vedas contain traces of their rituals. Their kings sacrificed horses and they drank soma, a potion with magical properties. Because of the importance of the Vedas, this early stage in the history of the subcontinent is often known as the "Vedic period." One of the rituals described in the Vedas is Ashvamedha, horse-sacrifice.

In India, mathematical knowledge always developed in conjunction with its practical application. Already the Harappa civilization, some 
2,500 years BCE, used geometry in order to calculate the size of fields. Indian mathematicians calculated the value of pi with a very high degree of precision, and determined the circumference of the earth and the timing of lunar and solar eclipses.

Alexander the Great and his armies moved into the Punjab, in the northwestern corner of the subcontinent. Once in Punjab, however, his troops rebelled and he was forced to turn back. Shortly afterwards, only thirty-three years old, he died in Babylon. The chaos of his failed invasion provided an opportunity for others to assert themselves. The Mauryans overthrew the various mahajanapada kingdoms. They ruled an Empire which for the first time encompassed almost all of India only the southern tip of the subcontinent remained outside of their control. The most famous of the Mauryan kings was Ashoka the Great. Ashoka renounced violence after ruling ruthlessly, converted to Buddhism being remorseful and disgusted with his previous way of life, and he started a number of projects to improve the welfare of the poor, the aged and widowed.

Industrialization refers to the process whereby the cultural practices of the Indian subcontinent, together with aspects of its political and social system, came to influence the rest of Asia. Despite this fact, India has had a profound impact on societies elsewhere. This power has been civilization rather than political and it has relied on exchange rather than political and it has relied on exchange rather than on the force of arms. In the third century CE, there were already well-established contacts between ports all around the Indian Ocean. This was where Indian merchants came to settle.

After the death of the prophet Muhammad in Medina in 632, his followers on the Arabian Peninsula quickly moved in all directions, creating an example which only one hundred years later came to include not only all of the Middle East and much of Central Asia, but North Africa and the Iberian Peninsula as well. This was known as the caliphate. The first, the Rashidun Caliphate, 632-661, was led by the companions who were the family and friends of the prophet Muhammad. The second caliphate, the Umayyads, 661-750. The third caliphate, the Abbasids, 750-1258, presided over what is often referred to as the "Islamic Golden Age," when science, technology, philosophy, and the arts flourished. The third caliphate was the Ottoman Empire with its capital in Istanbul, the city the Greeks had called Constantinople. The Fatimid Caliphate, 
909-1171, is usually considered as the last of the four original caliphates which succeeded the prophet Muhammad. The Fatimids were originally Berbers from Tunisia but claimed their descent from Fatimah, the prophet's daughter. They were Shia Muslims, which make them unique among caliphs. The followers were the custodians of the revelation as given to Muhammad and their task was to spread the word and convert infidels to the new faith. The new leaders of the community must consequently, many felt, combine the qualities which had characterized Muhammad to be a religious leader but also a politician and military commander.

Arab expansion may best be explained not by a religious but by a military logic. Thus, when the advance of the Muslim forces throughout Europe was eventually halted at the Battle of Tours in 732, this was regarded as a major triumph by European observers but merely as a temporary setback by the Arabs themselves. They simply retreated in order to fight another day.

Since most land between Europe and Asia was sparsely populated and quite unprotected, the Mongols quickly overran an enormous territory while most of the actual warfare consisted of sieges. Once they had mastered the art of siege warfare, the cities too built a navy and tried to invade both Java, and Japan. In 1241 they completely obliterated the European armies that had gathered against them and in 1258 they besieged, sacked and burned Baghdad. The Mongol Empire lasted only some 150 years. The political structure had already begun to crack by the middle of the thirteenth century and by the early fourteenth century it was disintegrating. At the end of the fourteenth century; the Mongol Empire was once again a small kingdom confined to the Steppes north of China. Its last remnant was conquered by the Manchu armies in 1635. Other vestiges of the Mongols and their descendants lived on, most successfully in the form of the Mughal Empire in India, founded in 1526 by Babur who counted himself as a direct descendant of Genghis Khan.

The boy who was to become Genghis Khan was born in 1162, not far from the current Mongolian capital of Ulaanbaatar. He was given the name Temujin. In 1206, he took the name "Genghis Khan" for himself. The people he united came to be called "Mongols" after the name of his own tribe. The people who were loyal to him he treated as family members, while those who crossed or betrayed him were given no mercy. Once 
in power, Genghis Khan put in place a legal and institutional framework that would help break the cycle of violence in Mongol society and prevent the kinds of events that had wreaked havoc in his own life. One aim was to abolish the traditional divisions into tribes, clans and lineages. Consequently Genghis Khan abolished aristocratic title and promoted people according to merit.

Two separate waves of expansions have served to unite the African continent the Arab invasion and the Bantu migration. The Arab invasion connected North Africa to the caliphates in the Middle East and thereby to prosperous centers of civilization. Likewise, the Bantu migration spread kindred languages throughout the continent together with cultural practices and technical know-how. Yet it was trade which more than anything brought the continent together. The trade in gold, salt and slaves was particularly brisk and it was the profits derived from these key commodities that convinced Berber merchants to cross the Sahara, and that took Arab down the Swahili coast. This is also what eventually brought European explorers and merchants to Africa. It was by taxing this trade that city states grew rich and expanded into kingdoms and empires. It was also trade which more than anything allowed people to escape their ecological niches. Trade made cities spring up in the desert and gave the people of the jungle the resources they needed to cut down even the tallest of trees.

But relations were not always peaceful. The groups of people living in the rainforest often conducted raids on each other, and the states on the savanna relied on powerful armies which could subjugate and enslave their enemies. Yet wars in Africa were different from many wars fought elsewhere. Since land was an abundant resource, it was not worth fighting over. The only proper exceptions to this rule are the Yoruba city-states in the Niger Delta of Nigeria, which were very concerned indeed about territorial boundaries. Political leaders were content to raze the capital of the enemies they had defended, humiliate them and include them as a subordinate partner in an alliance. The subordinate state would become a tribute bearer who brought gifts to the Suzerain state. This is how the empires of Africa were created.

Taken together, the Americas, North and South, cover an enormous geographical area which runs from one polar region to the other, com- 
prising all kinds of climate and ecological environments including rainforest, deserts, prairies and some of the highest mountains in the world. There had been at least three major empires in the Americas the Maya and the Aztecs in Central America and the Incas in South America. In North America, meanwhile, societies were smaller and more dispersed. Despite the enormous distances involved, trade connected these various communities in North America, for example, sold turquoise to the Aztecs. Neighbors fought each other in bloody wars, made peace and forged alliances.

There were many political similarities too. For one thing, the empires of the Americas had societies that were as hierarchical as their pyramids. At the top of society there was an aristocracy, a priestly class and a king who was associated with the sun and treated as a deity. Ordinary people had few rights and many obligations but they were at the same time subjects of the benevolent care of the state. This was most obvious among the Incas where there were no economic markets and no money, and where the government instead provided all the goods, including foodstuffs, which people could not produce themselves.

The most notorious performances staged in public places such as squares and on the top of pyramids were the public rituals which included sacrifices of human beings. The aims of the rituals was religious to convince the sun to rise in the sky, to keep away sickness, and to ensure another year of plentiful harvests. However, the aim was also political: human sacrifices were a means of instilling terror both in the emperor's enemies and in his own subjects. Human sacrifices were public displays of power. Many of the people sacrificed were prisoners of war.

European expansion is a story of imperialism and colonialism. In the first half of the fifteenth century, Europeans began to embark on sea voyages which took them down the western coast of Africa, and eventually far further afield. Here they discovered a number of commodities which found a ready market back home. Before long the Europeans began looking for new goods and for opportunities to trade. The commercial activities transformed Europe's economy and enormously strengthened the institutional structure of the state. It was at this point that the Europeans established their first permanent colonies overseas. In some areas, such as in the Americas, Europeans settled permanently, but in Asia they mainly established small trading posts. 
Beginning at the end of the eighteenth century, the development of an industrial economy based on mechanical production in factories radically changed European societies, making them "modern." Modernization entailed changes in almost all aspects of social, economic and political life.

As a result of the industrial revolution, and the relentless pace of economic development it unleashed, the Europeans gained a new sense of self-confidence. This radically changed their view of the rest of the world, and of Asia in particular. From the first faltering contacts in the middle ages to the end of the eighteenth century, the Europeans admired and looked up to Asia. However, in the first part of the nineteenth century, almost overnight, Asia became an object of scorn. The problem, more than anything, was that Asia had failed to develop in the European fashion. Asia had missed out on the industrial revolution.

\section{THESIS OF THE BOOK}

Ringmar opined that for much of its history, China was the dominant country in East Asia and international relations in this part of the world were, more than anything, organized by the Chinese and on Chinese terms. China itself was an empire but the international system of which China was the center concerned the external relations of the empire its relations with the rest of East Asia. According to him, from Korea, Japan and states throughout Southeast Asia the Chinese emperors demanded tributes. The foreigners were required to make the journey to the Chinese capital at regular intervals and present gifts to the emperor. In this way the Chinese were confirmed in their views of themselves. They really were the country at the center of the world the "Middle Kingdom" to which all human beings paid tribute.

The author reiterated that what made a person Chinese, and what brought a sense of unity to the Chinese people, was not state power but more than anything a shared set of rituals and seasonal celebrations. These rituals go way back in time. The first rulers the Shang dynasty, 1600-1046 BCE engaged in human sacrifice and ancestor worship. They were also the first to use characters divinations inscribed on so-called "oracle bones" 
as a means of writing. He went on, while human sacrifice soon ceased, ancestor worship and the unique Chinese form of writing have survived to this day.

According to Ringmar, in Japan, the Art of War was used as a textbook in military academies at the end of the nineteenth century. Admiral Togo Heihachiro, who destroyed the Russian navy at the Battle of Tsushima in 1905, was reputed to have been an avid Sunzi reader. The Japanese victory in the war with Russia was the first time since the Mongols that an "eastern people" had defeated a "western people." Also, Ho Chi Minh, leader of the Vietnamese independence movement, translated portions of the book and it was read by Vo Nguyen Giap, the general who defeated the French army at the battle of Dien Bien Phu in 1954. The author wrote: this was when Americans started reading Sunzi. Much as in Japan, the book was used at military academies and it was suggested reading for American officers dispatched to Vietnam. This was how a Chinese military manual from the fifth century BCE became readily available in bookshops the world over.

Although one dynasty was constantly replaced by another, Ringmar wrote, several of the dynasties were not Chinese at all, but established by foreign invaders. Despite this political diversity, there is a striking continuity when it comes to cultural values. Most of the emperors embraced Confucian ideals and were active participants in the various rituals which Chinese culture prescribed including ancestor worship and offerings to Heaven at various times of the day, month and year. The emperors saw themselves as "Sons of Heaven" who ruled by virtue of the mandate that Heaven had given them.

Ringmar claimed that nomads were always potentially on the move, and since they never stayed long enough in one place, they could not accumulate many resources. The Chinese, by contrast, were overwhelmingly farmers and some were city-dwellers, meaning that they lived sedentary lives and stayed in one place. Every Chinese family had a home, be it ever so humble, which they were prepared to defend with their lives. And, of course, some Chinese families were very wealthy indeed. To the nomads this constituted an obvious temptation. The nomads were interested in all kinds of resources as long as they were portable gold and silver, animals, and women and children who could be turned into slaves. 
The author recorded, despite the official Confucian doctrine which said that China was self-sufficient in all things, many Southeast Asian merchants discovered the Chinese to be interested not only in spices and hardwoods but also in special items such as rhinoceros horns and ivory. And there was, of course, no end to the things which the foreigners might buy from the Chinese.

The author recalled the Confucian scholars pointed out that, while farmers toiled in the field, merchants got rich without breaking a sweat. Lacking an economic rationale for the activity, the imperial authorities instead interpreted foreign trade in cultural terms. China, they argued, was the most sophisticated country in the world and, by comparison, everyone else was a "barbarian."

During the Ming dynasty there were altogether 123 states which participated in these ceremonies, although many of the entities in question showed up only once and some of the more obscure names of the list may indeed have been fictional. Ringmar also recorded, during the Qing period, the records became more accurate, with a core group of states regularly undertaking missions. These included Korea, Siam, the Ryukyu Island, Annam, Sulu, Burma, Laos, Turfan, but also the Portuguese, the Dutch, and the British. The Europeans were represented by their respective trading companies. One may wonder why the foreigners agreed to submit themselves to these exacting requirements, Ringmar was of the opinion the answer was that they wanted to trade with the Chinese.

The author agreed it is unclear how the Japanese first came into contact with China, but it is easy to imagine that Japanese fishermen were washed up somewhere on the shores of the Asian mainland after a storm. When they eventually made it back to Japan, they had amazingly stories to tell about all the wonders they had seen. Hearing such tales, the local rulers dispatched better-organized delegations, and soon the Japanese embarked on regular study-visits. Eventually, the Japanese imported an entire culture from China, including arts and technology, religion, a writing system, political and social thought, and associated political and social institutions. Among the institutions borrowed from China was that of an emperor, yet the emperor of Japan was nowhere near as powerful as his Chinese counterpart.

India, just as China is not a country as much as a world in itself. Indeed, it is often referred to as a "subcontinent" which includes not only 
India, but today's Pakistan, Bangladesh, and Sri Lanka as well. The first human settlements in India go back at least 9,000 years. In the valley of the Indus River, the first organized states were established some 5,000 years ago. There are more than 2,000 separate ethnic groups in India, often with their own language and customs. In addition, India is the origin of two world religions, Hinduism and Buddhism, and of smaller religions too, such as Jainism and Sikhism. By 2024, it is estimated that India will overtake China as the country with the largest population in the world.

According to Ringmar, the reason for the invasions in India was always the same: the extraordinary wealth of the Indian subcontinent. In India everything grew in great abundance; in the fertile rice fields of the South it was possible to gather two, sometimes three, harvests per year. In the Classical period roughly during the first millennium of the Common Era India must have been the richest country in the world. And well after that duty the Mughal period India continued to be known as the emporium mundi, the world's greatest hub for trade and manufacturing.

The author identified the influences of Indianization: it is because of Indianization that today's Thailand is a Buddhist country, that Angkor wat in Cambodia was originally built as a Hindu temple complex, and why a majority of people in Indonesia are Muslims. He went further to state that the influence of Indian culture on non-Indians remains strong to this day although the impact is now felt on a worldwide scale.

The author was of the opinion the Indo-Europeans, at least according to one prominent theory, came from Central Asia sometime around 2,000 $\mathrm{BCE}$ and established themselves in northern India, along the plains of the Ganges River, as well as on the Deccan Plateau in central and southern parts of the subcontinent.

All kings in Vedic India performed the Ashvamedha, and the ritual declined only in the latter part of the Gupta period. New-age Hindu spiritualists have recently tried to revive the Ashvamedha ritual, but they use a statue of a horse rather than kill a live one. Apparently, devotion to the horse can help one defeat enemies and clear debts, Ringmar drafted.

The author recalled the history of mathematics is a great example of a civilizational exchange. The Indians learned maths from the Greeks and taught it to the Arab world, who in turn taught the Europeans. At each stage, the knowledge was transformed and improved upon. To this day 
only some 10 percent of all the manuscripts on Sanskrit science have been published and much remains to be properly studied.

Ringmar was of the opinion that one invasion which was to have a profound impact on India was the Great Alexander's failed invasion. $\mathrm{He}$ explained, Alexander was a Greek statesman and general who had already successfully fought the Persians and continued eastward from there. In this way he created a vast, if short-lived, empire which stretched from Europe all the way to India. India, the Greeks believed, was where the world ended and by conquering it, Alexander would come to rule the whole world. Alexander's failed invasion was how the first India-wide state, the Mauryan Empire, came to be established. Asoka the Great was a Mauryan king. The author recalled legend has it he killed no fewer than ninety-nine of his brothers, and once he assumed power he continued to be selfish and cruel. Yet he eventually came to regret his behavior and in addition to his awakened projects he put up pillars all over his empire on which he explained his policies and his aspirations. Today, there are still thirty-three of the pillars in existence.

The term Indianization, as recalled by Ringmar, was first used by Indian nationalists in Bengal in the 1920s, at the time when India was still a British colony. Inspired by French excavations of Angkor Wat and other ancient temple sites, they began to speculate regarding the existence of an ancient "greater India" which had spread out over much of East Asia. This had not been an empire, they explained, but rather a civilization. India had brought progress and prosperity to its neighbors but not, like the British, through military conquest, but instead through trade and peaceful exchange.

Ringmar recalled the Umayyads Caliphate moved the capital to Damascus in Syria. And while it did not last long, one of its off shots established itself in today's Spain and Portugal. He recalled that Baghdad was the capital during the Abbasids Caliphate, a center in which Islamic learning combined with influences from Persia, India and even China. Which Cairo later constituted the center of the Muslim world after the Mongols sacked Baghdad in 1258. Although Cairo too was quickly undermined. He also identified the Ottomans to be Muslims, although not Arabs but Turks, and they had their origin in Central Asia, not on the Arabian Peninsula. 
Despite the community story of political infighting and fragmentation, the idea of the caliphate continues to exercise a strong rhetorical force in the Muslim world to this day. The author agreed that during the caliphates, the Arab world experienced unprecedented economic prosperity and a cultural and intellectual success which made them powerful and admired. Not surprisingly perhaps, the idea of restoring the caliphate is still alive among radical Islamic groups who want to boost Muslim self-confidence. The term jihad, "holy war," is often used to describe this military expansion, yet political control, not religious conversion, was its main objective.

Although the occupation of lands outside of the Arabian Peninsula happened exceedingly quickly, converting the occupied populations to the new faith took centuries to accomplish, and in many cases, it never happened. As a result of its military victories, Islam became a minority religion everywhere the Arabs went and forced conversions were for that reason alone unlikely to prove successful. Moreover, conversions were financially disadvantageous to the authorities.

According to the author, the Fatimids founded the al-Azhar mosque there in 970, and also the al-Azhar University, associated with the mosque, where students studied the Quaran together with the sciences, mathematics, and philosophy. Al-Azhar University is still the chief center of Islamic learning in the world and the main source of fatwas, religious ruling, and opinions.

At the height of their power the mongols controlled an area which stretched from central Europe to the Pacific Ocean. It was a territory about the size of the African continent and considerably larger than North America. Ringmar recorded, although the Mongols counted only about one million people at the time, the lands they once controlled comprised today a majority of the world's population.

The Mongols were known as merciless warriors who destroyed the cities they captured, sparing no humans and occasionally even killing their cats and dogs. Yet apart from the military superiority, they had nothing much to impart to the rest of the world. The Mongols made no technological breakthroughs, founded no religions, built no buildings, and they not even mastered simple techniques such as weaving, pottery or bread-making. The writer included the only thing the Mongols built were bridges. 
Bridges were crucial for allowing armies to mobilize and giving merchants free passage. The Mongols built them whenever they were needed. They were also experts at breaching walls. They recruited Chinese engineers who taught them how to construct siege engines. Before long the Mongols were building their own catapults, trebuchets and battering rams, and siege warfare being the only area in which they made technological advances.

According to the author, in the latter part of the fourteenth century, the bubonic plague hit first China, then the Mongols, the Arabic world and finally Europe in a series of successive waves. It is estimated that some 75 million people died worldwide and that China lost between one-half and two-thirds of its population, and Europe perhaps half. The disease had a profound and immediate impact on commerce and on the Mongol Empire itself.

Ringmar was of the opinion that all human beings are Africans. It was in today's Ethiopia some 200,000 years ago, that the first settlements of Homo sapiens were established. From this origin we gradually came to migrate to every corner of the planet. He opined that Africa is actually different than we think since the Mercator projection used for most world maps under represents the true size of territories around the equator and Africa straddles the equator.

Northern Africa, as recorded by the author, was one of the first parts of the world to convert to Christianity, with an important center of scholarship being Alexandria, in Egypt. The kings of today's Ethiopia converted to Christianity in the fourth century. Later in the seventh century, North Africa was overrun by Muslim armies. In the eleventh century, two Berber kingdoms, located in today's Morocco, invaded Spain.

Human beings, according to the author, began settling here some 20,000 years ago. Scholars are convinced that the first Americans wondered across the land bridge which at the time connected Asia and North America across today's Bering Strait, between Siberia and Alaska but there is an abundance of other, far more fanciful theories. From this time onward, although they had some contact with each other, the people of the Americas had no connection with the rest of the world. As a result, their societies developed entirely according to their own logic.

Europe was an international system focused on itself, confident in its own culture and largely uninterested in what was going on elsewhere. 
Moreover, outsiders like the Berber kingdoms in the eleventh and twelfth centuries and the Mongols in the thirteenth century found a few impressive cathedrals, the occasional castle, but also a lot of desperately poor people, serfs without much food and without education. Before the year 1500, no European city was a match for the splendors of Baghdad, Xian, Kyoto or Tenochtitlan.

The author recognized that history is constantly making itself present and today people and countries outside of Europe asserting themselves. $\mathrm{He}$ further affirmed that the world is once again changing and changes, once underway, can be quick and dramatic. Today, Europe and North America play a far less important role in world politics than in the past century, and in the future this role is likely to become less important still.

\section{ANALYSIS/ EVALUATION OF THE BOOK}

"The people to the north and the west constituted permanent threats. They were nomads who grazed their animals on the enormous steppes of inner Asia. Despite their economic and technological backwardness, they had access to the most advanced military technology of the day fast horses and in addition they were highly skilled archers... As far as China's relations with countries to east and the south were concerned, they were far easier to manage. Since the Himalayas effectively blocked any invasion from the south, there were no military threats from this direction and instead, communications took place across the ocean." (Ringmar, 2019, p. 13).

According to Ringmar, "Chinese people are fond of saying that their land has the longest continuous history of any existing country, yet the subject of this history "China," "the Middle Kingdom" has itself varied considerably overtime. What we mean by "the Chinese people" are also less than clear. People who historically have lived in what today is the People's Republic of China represent many hundreds of different ethnic groups... It was only in the latter part of the nineteenth century that it became possible to talk about a Chinese "nation," understood as a community of people which encompassed most of the country." (2019, p. 14).

Ringmar revealed that the Art of War came to be read as a manual, embodying a uniquely "eastern" way of making war. "This, at any rate, was 
how the book was understood by students from various East Asian countries who studied in Japan in the first decades of the twentieth century. Taking The Art of War home with them, they used it as a manual for how to liberate themselves from European Colonialism.” (2019, p. 15).

Ringmar recalled that moral conduct, as Kongzi saw it, is above all a matter of maintaining the obligations implied by our social relationships. Society in the end consists of nothing but hierarchical pair relations between: father and son, husband and wife, older and younger brother, ruler and subject, and between friends. The inferior party in each pair should submit to the power and will of the superior, but the superior has the duty to care for the inferior, to look after his or her welfare. A well-ordered society is a society in which these duties are faithfully carried out.

"In general, the closer the country was located in relation to China, the more often it had to present itself at the imperial court. The Koreans were put on a three-year cycle and they were thereby the most frequent visitors. Since they had to travel so far, the Europeans were supposed to make an appearance only every seventh year, but these regulations were, in practice, never followed. All in all, the Portuguese only made four visits to the imperial court, the Dutch also four, and the British three. The Russians showed up as well, altogether some twelve times, but since they were a part of the overland system they came from the north after all particular rules applied to them." (Ringmar, 2019, p. 35).

Ringmar analyzed the Japanese often changed the cultural imports to fit their own needs, and many of the changes were radical enough, but Japanese society was nevertheless profoundly altered as a result of the interaction. Ringmar further analyzed, the Japanese did not want anything to do with an aggressive and expansionist China. Although informal commercial contacts continued and thrived, no more official delegations were dispatched to the Chinese court. The imported Chinese culture continued to evolve, but in a distinctly Japanese fashion.

"Japan was decentralized, with many different centers vying for political power. There was, for example, a fundamental tension between the leaders who controlled the Kanto region, where today's Tokyo is situated, and the leaders who controlled the Kansai region, the area around today's Osaka and Kyoto. During the Kamakura period, 1185-1333, power was taken over by military leaders, the shoguns, for whom Kanto was 
their center... This was particularly the case during the Sengoku period, 1467-1573, which was Japan's own version of China's Warring States period. The Sengoku period was a time of lawlessness, heroism, and political intrigue with vast armies of Samurai pitted against each other." (Ringmar, 2019, p. 36).

According to Ringmar, in the case of India, there is no single political subject about which a story can be told. Instead, various states and empires have replaced one another. Today India is a country, but throughout most of its history, it would best be described as an international system. At the same time, it was an international system which was held together by a strong sense of shared identity based above all on Hindu practices and beliefs.

Ringmar described ashvamedha as one piece of evidence which locates the Indo-Europeans outside of India. He further narrated: "To the people of the steppe, the horse was a sacred animal, and horses were often buried together with dead kings. Horse sacrifices have been carried out all over the Eurasian landmass in China, Iran, Armenia, among the Greeks and the Romans, even in Ireland. In the Irish ritual, the king, had sexual intercourse with a mare who then was killed, dismembered and cooked in a cauldron in which the king proceeded to swim and drink from the broth." (2019, p. 47).

"Darius, the king of Persia, had put up similar monuments where he had boasted about the battles he won and the number of enemies he had killed. Ashoka, however, inverted this message. His pillars expressed his promise to rule his people with compassion and benevolence, to renounce violence and make sure that every one of his subjects was happy and wellfed." (Ringmar, 2019, p. 53).

"Since Indianization was never a matter of official policy. It is difficult to say exactly when the process began and how it developed; what is clear, however, is that Indian influences spread along trade routes, both in Central Asia and in the Indian Ocean... In Southeast Asia, a strong Indian influence is detectable from the eight century and it was to continue for at least five hundred years. This was when Hinduism spread, followed by Buddhism and then Islam. This was also how the Pali and Sanskrit languages were exported, together with Indian music, theater and dance, food, ways of dressing, and much else besides." (Ringmar, 2019, 
p. 58). Also, according to Ringmar, Indianization is not the spread of Indian culture as much as the creation of a new species of culture which draws heavily from India but, which at the same time is adapted to local traditions and needs. Indian culture has continued to have a profound impact on other societies, but in the twenty-first century, its influence is nothing short of global.

To briefly describe the success and operation of the Arabs' holy war, Ringmar wrote: "The secrets behind this astounding military success was a lightly armed and heavily mobile fighting force... Once they were formed into an army their horses could be used for swift attacks and their camels for transporting supplies. The neighboring empires the Greeks in Byzantium to the west and the Persians to the east were both stationary by comparison. As soon as the Arabs had mastered the basics of siege warfare, these sedentary societies were easily defeated." (2019, p. 74).

"In 1368, the Mongols lost control over their most prized possession China. One important reason for the decline and fall of the Mongol Empire was the perpetual infighting which took place among Genghis Khan's descendants. By the middle of the thirteenth century when his grandchildren were ready to take over the realm the question of succession turned out to be impossible to settle. The outcome was a civil war which turned brothers against each other and eventually resulted in the division of the empire into four separate realms the Golden Horde in Russia, the Ilkhanate in Persia, the Yuan dynasty in China, and the Chagati Khanate in the traditional heartlands of Mongolia." (Ringmar, 2019, p.102).

Ringmar described the Mongols as having singular bad press. According to him, "they are known as blood thirsty barbarians who annihilated entire cities, killing all inhabitants together with their cats, and dogs. And the Mongols did indeed use terror as a means of defeating their enemies, but it is not clear that their way of making war was substantially more destructive than that of other people at the time or indeed, more destructive than wars fought today. Another question concerns their long-term impact on the societies they included. In China, Russia and the Middle East, the Mongols have often been blamed for causing economic and cultural stagnation. Arab scholars have pointed to the destruction of Baghdad as the pivotal events that ended their "Golden Age" right at the time when the revival of learning was making Europe increasingly dynamic. Chinese 
scholars have similarly faulted the Mongols for ending the Song dynasty during which China came tantalizingly close to embarking on an industrial revolution of its own. Some Russian scholars, meanwhile, have blamed the Golden Horde for the facts that Russia never managed to keep up when the rest of Europe was modernizing." (2019, pp. 120-121).

Ringmar analyzed, that there are good reasons to conclude that there is no such thing as an African international system. After all, in many parts of Africa, geography and climate have created obstacles to the formation of the kinds of political structures which we think of as states. In the rainforest, he continued, the vegetation was usually too dense to clear and no large communities could be formed and further inland people were often pastoralists and not that easy to organize politically. And if there are no states, there can be no inter-state system. Yet one's ecological niche is not one's fate, and Africa has been full of mighty empires, elaborate political structures and unimaginably wealthy kings. Even the most remote locations have been connected to international trading networks.

Ringmar divided the African continent into regions. The most commonly made distinction is between "North Africa" and "Sub-Saharan Africa," with the Sahara desert diving the two. The author wrote, "North Africa has a coastline along the Mediterranean Sea and from the very beginning people here have interacted with populations in the Middle East and Europe. Pharaonic Egypt, one of the world's oldest civilization, dating back to $3000 \mathrm{BCE}$, is located in North Africa, and so is Carthage, in today's Tunisia, which for hundreds of years was Rome's main adversary. South of the Sahara in Sub-Saharan or "Black" Africa most people speak Bantu languages. The Bantu speakers originated in western and central parts of the continent but started moving east and southward in the first millennium BCE, spreading their language, cultural practices and crafts."

"A study of comparative international systems is by definition a historical study. There are no separate international systems to compare anymore. There is only one system the system which first made its appearance in Europe in the late Renaissance, and which later came to spread to every corner of the globe. But "spread" is not the right word. This was not a matter of a process of passive diffusion. Rather, the eventual victory of the European international system was a result of the way the Europeans 
first came to "discover" and later to occupy and take possession of most non-European lands." (Ringmar, 2019, p. 179).

\section{CONCLUSION}

The author, Ringmar, wrote he would tell the history of international relations in a way that is not Eurocentric: to tell the history of each part of the world and how they had related with the world and not how Europe had influenced every part of the world; of which he did, and should be commended for a good work. But as identified, by telling a comparative international system, the author had either misrepresented the past by telling the history of the states and not the history of stateless people, or had incompletely presented the past by mostly telling the history of of the states and only a flash of the stateless people.

\section{RECOMMENDATION}

This book is recommended to all since it spans across the world, recording the culture and traditions of each respective part of the world, and how they have all related with other parts. But, more specifically, it is recommended to students and history scholars in fields of international relations, public relation, as well as political science and international politics. 